821.163.41.08 Петровић Његош П. II

811.163.41'367.6

https://doi.org/10.18485/sj.2021.26.1.1

РАДМИЛО Н. МАРОЈЕВИТ

Универзитет у Београду

Филолошки факултет
Оригинални научни рад

Примљен: 10. 11. 2020.

Прихваћен: 12. 1. 2021.

\title{
ВЕРБАЛИЗАЦИЈА ТЕКСТА ШЋЕПАНА МАЛОГ (Реконструкција растављеног писања)
}

\begin{abstract}
У серији радова под горњим насловом ${ }^{* *}$ разматра се подјела текста Његошевог спјева Шћепан Мали на ријечи, па се издваја растављено писање (које је предмет овог чланка), састављено, полусастављено, тј. с дивизом, и растављено у акценатском а састављено писање у критичком и основном издању, што је у складу с теоријском концепцијом о вербализацији текста (подјели текста на ријечи).

Кључне ријечи: Петар II Петровић-Његош, спјев Шћепан Мали, спјев Горски вијенаи, спјев Луча микрокозма, учење о врстама ријечи.
\end{abstract}

\section{І. ПРИСТУП}

0.1. У издању Шћепана Малог требало је рјешавати бројна текстолошка питања, исправљати штампарске и редакторске грешке првог издања и освјетљавати „тамна мјеста” у тексту, па и примјере неадекватне вербализације текста (подјеле текста на ријечи).

Вербализација текста, тј. његово рашчлањивање на ријечи као самосталне лексичке, лексичко-граматичке и граматичке јединице, један је од

*radmilo@mail.ru

** Из пројекта „Пјесничка дјела Петра II Петровића-Његоша у оригиналу и руским преводима" Института за славистику и филологију Паневропског универзитета Апеирон у Бањој Луци. 
примарних текстолошких задатака. Писање растављено (1), састављено (2), полусастављено, тј. с дивизом (3), и растављено у акценатском а састављено у критичком и основном издању (4) - заснива се на теоријској концепцији о вербализацији текста (подјели текста на ријечи).

0.2. Растављено се пише веза двије ријечи за коју је утврђено да се она није лексикализовала. Више сегмената текста Шћепана Малог који се обично сматрају једном лексичком јединицом потребно је, по нашем мишљењу, рашчланити на двије ријечи.

У нашем критичком издању Шћепана Малог растављено се пишу: а) фонетске ријечи с проклитиком (рјечцом или везником) $u$, као и рјечца $u$ и ријеч која јој претходи [види т. 1], б) напоредо употријебљени везници ка и да у живој граматичкој функцији [види т. 2], в) рјечца дё у значењу 'сем' у вези с прилогом сӓд, везник тё у значењу ‘и то’ у вези с прилогом лӥш и копулативни облик нй(j)e испред придјева криิв [види т. 3], г) дво- и трокомпонентни везници с рјечцом ли у своме саставу [види т. 4], д) аналитичке неодређене замјенице које се образују од упитно-односних замјеничких ријечи с рјечцом гӧд [види т. 5], ђ) веза саставног везника $u$ и условног везника ӓко, при чему акценат остаје на компоненти ӓко [види т. 6], е) реченична конструкција коју чине субјекат свё (облик средњег рода замјенице који није граматикализацијом прешао у рјечцу нити транспозицијом у префикс) и предикат је јёдна̄ко чија је копула, након губљења интервокалског $j$, са замјеницом срасла у диверб

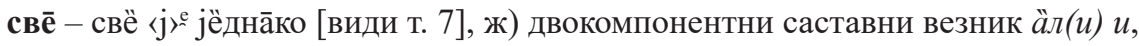
у значењу 'и', 'а и', 'али и' и комбинација копуле $е$ и рјечце ли с рјечцом $u$ у фразеологизму је ли и Бог дао [види т. 8], з) комбинација везника нй односно нӥт с глаголском енклитиком сам и одричне рјечце ни (која није прерасла у префикс) с бројем један [види т. 9], и) везе именица и замјеница с енклитикама: ама̀нат ти, она̀ко̄ га и узвичним рјечцама у проклизи: ё тоे, ӧ Кану́ни [види т. 10], j) придјевско-именичке синтагме у којима је прва компонента атонирана па је пренесен акценат с друге компоненте: (ак.) злу́ cpeћy, (по) свѐ љето [види т. 11] и к) предлошко-падежне везе које се нису (потпуно) граматикализовале, тј. које нису потпуно прешле у сложене предлоге, и које чувају самосталан именички акценат (без преношења на примарни предлог) и именичко значење: „на срёд + генитив”, „у днӧ (пӧ днӧ, са днӧ) + генитив”, „на верх (са вӥх) + генитив” [види т. 12].

0.3. Поред тога, растављено се пишу и неке друге предлошко-именичке и предлошко-прилошке везе које се нису (потпуно) адвербијализовале - у којима именица односно прилог чува своје значење а акценат се не преноси или се преноси факултативно на предлог, као и веза предлога и компаратива прилога која није прешла у предлог (компаратив чува свој акценат и значење), али се оне описују у раду Маројевић 2021а. 
0.4. У раду се, гдје је то било потребно и могуће, примјењује поредбена анализа с контекстима друга два Његошева спјева, Горског вијениа и Луче микрокозма, као и пјесме Поздрав србском роду (из које је узет мото спјева), док се у одјељку „Исходи” [види т. 13] синтетички представљају конкретни поступци у доказивању вјеродостојности интерпретације форми и значења контекста̂ анализираног спјева.

\section{II. ТИПОЛОГИЈА РАСТАВЉЕБОГ ПИСАЬА}

1. Растављено треба писати рјечцу $u$ и ријеч чија је она проклитика, односно рјечцу $u$ и ријеч која јој претходи, у четири контекста Шћепана Малог (и у једном контексту Горског вијениа). У три стиха ми смо васпоставили растављено писање, а у два га први успоставили.

(1) У другом полустиху 24. стиха (па ћеш $и$ скочити):

Стӓн сердаре (лаковјеран ли си!):

прйђ’ оммјери па ћеш и скочити -

ко посрне, мудро̀ват му бране!

[ШМ 23-25]

није представљен глагол *искочити него комбинација „рјечца $u+$ глагол скочити".

Неадекватно, састављено писање налазимо у првом и у бројним каснијим издањима: Прић' омјери, па ћеш искочити; [Столковић 1851: 10; Јов Ановићи 1880: 12; Костић 1902: 10 (24); Решетар 1926: 187 (I 24); Вушовић 1935: 155 (исто у издању из 1936, с. 170); С тев Анови Ћ 1952: 14 (грешка није исправљена у каснијим издањима иако је Јевто Миловић, у међувремену, текст правилно рашчланио), исто у НЕди ъ 1964: 14].

Правилну вербализацију текста налазимо у издању Јевта Миловића: Прић' омјери, па ћеш и скочити; [Милови ъ 1965: 16 (Ì 24)], што значи да је он први исправио грешку претходних издања; исправку је прихватио Александар Младеновић [МлАдЕнови 2007: 140 (24)].

НАПОМЕНЕ.

1. Анализираним примјером илуструје се значење „2. хитро изићи, истрчати одоздо горе" глагола иско̀чити у Речнику Његошева језика [СтЕвАновић и др. 1983 I: 292]. Уз правилну вербализацију текста, односно уз раздвајање рјечце $u$ од глагола, примјер треба премјестити у значење „1. учинити скок" глагола ско̀чити [С тев АН ови һ и др. 1983 II: 295], гдје се већ налази примјер из 1976. стиха Горског вијенцุа (скочи с мјеста четрнаест ногах). 
2. У 24. стиху Шћепана Малог представљена је изрека као фразеолошки жанр: прво омјери, па скочи! (у значењу 'прво процијени, па онда оцијени'), прилагођена структури десетерца. Слично значење има изрека трипут мјери, једном сијеци. Његошева изрека упоредива је с изреком прво скочи, па реци: xon! (у значењу 'прво уради, па се онда хвали') - обје изреке садрже глагол скочити, једна у финалној, друга у иницијалној семантичкој позицији.

(2) У другом полустиху 592. стиха (био нам и срёћан):

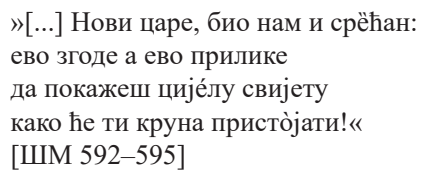

посвједочен је ненаглашени датив личне замјенице нам у комбинацији с рјечцом за истицање $u$, па их треба писати растављено.

Неадекватно, састављено писање налазимо у првом: Нови, Царе, био нами срећан! [Столкови 1851: 32] и другом издању: Нови царе, био нами срећан! [ЈовАновићи 1880: 30].

Правилну вербализацију текста налазимо већ у трећем издању, Драгутина Костића: Нови царе, био нам и срећан! [Костић 1902: 37 (код њега је то 595. стих)]. Исправку прихвата Данило Вушовић [Вушовић 1935: 170 (код њега је то 598. стих првог чина), Вушови и 1936: 186 (сада је то 595. стих)].

Милан Решетар враћа погрешну вербализацију текста из првих двају издања (он је исправке вршио на примјерку издања браће Јовановића): Нови царе, био нами срећан! [РЕшет АP 1926: 206 (I 598) (грешком коректора, стих је увучен умјесто да само почне великим словом; техничку грешку увлачења стихова у којима је Решетар био оставио велико слово поновиће Данило Вушовић у свом првом издању, али он и у другом издању све стихове почиње великим совом)].

Умјесто правилне, Костићеве вербализације текста, коју је у оба своја издања примијенио Вушовић, у издањима послије другог свјетског рата понавља се Решетарева грешка: Нови царе, био нами срећан! [СтевАнови 1952: 37 (I 595), исто у каснијим издањима и у Неди һ 1964: 32, Миловић 1965: 44]; Александар Младеновић грешку понавља, али и именицу пише великим словом: Нови Царе, био нами срећан! [МлАдЕнови и 2007: 52 (595)].

Растављено писање ми смо васпоставили, с образложењем, у основном издању Његошевих спјевова [МАро јеви ъ 2018: 53, 311].

(3) У 2607. стиху уз растављено писање-рјечце $u$ и претходне (одређене) замјенице $c \hat{a}$ - реконструишемо и предлог $c$ испред инструментала наредне (повратне) замјенице сӧбо̄м: 
забаве ти друге не има́дем

до једно́га са́ма разговора

с живијема али с мртвијема,

кад нй с једнйм - онда са̂м и [c] сӧбо̄м.

[ШМ 2604-2607].

Неадекватно, састављено писање налазимо у прва два издања: Кад ни с једним онда сами собом. [Столковић 1851: 124; Јов Ановићи 1881: 103].

Правилну вербализацију текста, али без васпостављеног предлога, налазимо већ у трећем издању, Драгутина Костића: Кад ни с једним, онда сам и собом. [Костић 1902: 147 (2681)].

Милан Решетар враћа погрешну вербализацију текста из првих двају издања (он је исправке вршио на примјерку издања браће Јовановића), али ставља прозодијске знаке: кад ни с једним, онда са̂мй собом. [РЕшет АР 1926: 284 (ÌV 111)]. Грешку понавља Данило Вушовић, али без прозодијских знака и без запете [Вушови и 1935: 233 (исто у другом издању, с. 259)].

Умјесто правилне, Костићеве вербализације текста, послијератна издања Његошевих Ц(j)елокупних д(j)ела, најприје у девет, а онда у седам томова (посљедње, прекомпоновано издање у четири тома), понављају Решетареву текстологију: кад ни с једним, онда са̂мй собом. [С тевАнови Ћ 1952: 37, исто у каснијим издањима (с. 138) и у НЕди һ 1964: 113].

Задржавајући састављено писање, текстолошки проблем су покушали да ријеше, најприје Јевто Миловић, правећи од номинатива замјенице сам инструментал: кад ни с једним, онда сами[м] собом. [Миловић 1965: 168 (IV 111)], а онда и Александар Младеновић, васпоставивши и предлог [c] испред Миловићевог инструментала: кад ни с једним, онда [c] сами[м] собом. [МлАДЕНОвИЋ 2007: 164 (2680)].

У Речнику Његошева језика замјенице са̂м и са̂мй наводе се као видски парњаци, а израз „сам (и стиха ради - са̂мӣ) собом (говорити)” [СтевАновић и др. 1983 II: 252, s. v. câм] тумачи се као фразеологизам, с двије потврде. Прва је с почетка Горског вијенща, испред првог стиха, у којој смо ми васпоставили предлог $c$ : Владика Данило (са̂м [c] сӧбо̄м), што чинимо и у овој другој потврди, из Шћепана Малог, уз растављено писање граматичке ријечи $u$ (рјечца која се може посматрати и као везник) и номинатива једнине мушког рода одређене замјенице са̂м.

Растављено писање, реконструишући рјечцу $и$ од које је полазио једино Костић, ми смо васпоставили, с образложењем, у основном издању Његошевих спјевова [МАролеви и 2018: 53, 394]. 
(4) У првом полустиху 3089. стиха (ваิм и чӱти):

»[...] И да хоће, помо̀ћ ви не смије,
и да смије, помо̀ћ ви не може -
он је са̀б'јен нӓ кра̄j ӧд свијета
те не може нй од које̄ ру́ке̄
ва̂м и чӱти смрти ни живота.«
[ШМ 3085-3089]

посвједочен је наглашени датив личне замјенице вам у комбинацији с рјечцом $u$, па их треба писати растављено.

Неадекватно, састављено писање налазимо у свим издањима сем наших: Вами чути смрти ни живота. [Столковић 1851: 143; ЈовАновићи 1881: 110; Кости 1902: 168 (3163)]; Милан Решетар и каснији приређивачи додају знак извода: Вами чути смрти ни живота.” [Решет АР 1926: 301 (IV 594) (грешком коректора, стих почиње великим умјесто малим словом) и Вушовић 1935: 246 (исто у другом издању, с. 274); с малим словом на почетку стиха у Стев Ановић 1952: 157 (IV 593), исто у каснијим Стевановићевим издањима и у НЕдИЋ 1964: 130, Миловић 1965: 194; МлАдЕновић 2007: 187 (3162)].

Растављено писање, реконструишући рјечцу $u$, ми смо успоставили, с образложењем, у основном издању Његошевих спјевова [МАРојеви 2018 : $53,412]$.

\section{НАПОМЕНА.}

У критичком, а потом и у основном издању Горског вијенца ми смо успоставили растављено писање предлошко-падежне везе $\ddot{y}$ помо̄ $u$, која је проклитика уз облик до́ђе: Мало ко нам ӱ помо̄ћ и дође; [ГВ 2715]. То значи да у другом полустиху није посвједочен (погрешни) локатив (у) *помоћи него правилни акузатив (у) помоћ у комбинацији с рјечцом $u$. У првом издању именица је била грешком одштампана састављено са рјечцом $u$ : Мало ко намъ у помоћи дође, [МедАковић 1847: 112], што су преписали сви каснији приређивачи. Иначе се израз у помоћ појављује још у два стиха Горског вијенца, и у оба је правилни облик акузатива: ӱ помо̄ћ нам ко год чу притече - [ГВ 2593]; Јошт нам ђѐко ӱ помо̄ћ прйскочй [ГВ 2786].

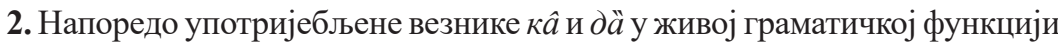
треба писати растављено, а компоненту ка̂ изговарати с дугосилазним акцентом, укључујући примјер у коме се у свим издањима која су нашим претходила неосновано рекоконструисао упитни замјенички прилог *ка̀да̄: ка̂ дӓ цари с пушкама шетају! [ШМ 373]. Ову синтагматску везу, у којој се као семантичка замјена у прозном дискурсу може користити двокомпонентни везник 'као да', треба разликовати од лексикализоване модалне ријечи, прилога ка́да с дугоузлазним акцентом у значењу 'изгледа'. У два се примјера (у истом кон- 
тексту) прилог ка́да може се семантизовати 'изгледа (да)': Опрости ми Боже свемогући: / ка́да нй ти главу не обрћеш [...] / ка́да ти је то најмања мйса̄ [ШМ 547-548, 550], али се подробном анализом (у раду Маројевић 2021б) доказује да се и у њима мора полазити од прилога ка́da, а не од двокомпонентног везника ка̂ да̄ у значењу 'као да'.

3. Растављено се пише рјечца дӧ испред прилога сӓд [види даље т. (1)], везник тё испред прилога лйш [види даље т. 2)] и копулативни облик нй(j)e испред придјева криิв [види даље т. (3)].

(1) У 2211. стиху примјењујемо растављено писање р ј е ц ц дё у значењу ‘сем’ и прилога сӓд:



Рјечца дӧ има и сама побочни акценат, мада се он испред акцентованог слога скоро не осјећа (неутрализован је), и на њега се акценат сљедеће ријечи не преноси.

Растављено писање налазимо и у прва три издања, али се тада и адвербијализована предлошко-прилошка веза по правилу писала растављено: Никад приђе до сад изнијели. [Столковић 1851: 105; ЈовАновићи 1881: 88; Костић 1902: 123 (2262)].

У каснијим издањима неосновано се полази од прилога *до̀сад, који је настао срастањем п р е д л о г а до и прилога сӓд: предлог до је атона ријеч, па се на њега п р е н о с и акценат с првог слога наредне ријечи (ако је акценат силазни): никад приђе досад изнијели. [Решет АР 1926: 267 (III 543); исто (с великим словом на почетку стиха) у Вушовић $1935: 220$, исто у СтевАновић 1952 : 115, НЕдић 1964: 95, Миловић 1965: 140; МлАдЕновић 2007: 140 (2262)].

Растављено писање васпоставили смо, с образложењем, у основном издању Његошевих спјевова [МАро еви и 2018: 52, 376].

(2) Растављено писање рјечце тё у значењу 'и то’ и прилога лӥш у значењу 'само' примјењујемо у три стиха.

$1^{\circ}$ У 2531 . стиху:

Ове горе не љубе рёгуле јер су у̀ њйх дани прёдуга̀чки (тё лӥш оेнӣм што код куће ча́мјӯ) кад их човјек не би потки́дао са пјесмицом и чашом ракије. [ШМ 2529-2533] 
у првом издању компоненте су одштампане састављено: Телиш оним што код куће чамју. [Столкови и 1851: 121].

$2^{\circ}$ У 2612. стиху:

Та ово је пријатно слушати, тё лӥш оेно̄м ко га чуо није.

[ШМ 2611-2612]

у првом издању компоненте су одштампане састављено: Телиш оном, ко га чуо није. [Столковић 1851: 124].

$3^{\circ}$ И у 3709 . стиху:



у првом издању примијењено је састављено писање: Телиш оним' који су одрасли [Столковић 1851: 171].

У другом издању спјева компоненте су растављене у прва два примјера: Те лиш оним, што код куће чамју. [Јов Ановићи 1881: 100]; Те лиш оном, ко га чуо није. [ЈовАновићи 1881: 103], док је у трећем примјеру остало састављено писање: Телиш оним, који су одрасли [Јов Анови ии 1881: 141]. Приређивач је примјере интерпункцијски уједначио. Даљи корак чини Драгутин Костић - он досљедно примјењује растављено писање: Те лиш оним, што код куће чамју. (2604); Те лиш оном, ко га чуо није. (2686); Те лиш оним, који су одрасли (3783) [Костић 1902: 143, 147, 198]. Растављено писање задржава Милан Решетар бришући непотребне запете: те лиш оним што код куће чамју. (IV 35); те лиш оном ко га чуо није. (IV 116); те лиш оним који су одрасли (V 301) [Решет А Р 1926: 281, 284, 323]. С обзиром на то да је писање великог слова на почетку стиха коректорска грешка, могла би се историја питања завршити с Решетарем. Растављено писање од Решетара преузима Данило Вушовић [Вушови и 1935: 231, 233, 264] задржавајући га и у свом другом издању.

Да се историја питања с Решетарем не заврши побринуо се Михаило Стевановић - он се враћа на Стојковићево текстолошко рјешење: телиш оним што код куће чамју, (IV 35); телиш оном ко га чуо није. (IV 116); телиш оним који су одрасли (V 301) [СтевАновић 1952: 133, 136, 185]. Стевановића слиједе Владан Недић [Недић 1964: 110, 113, 154] и Јевто Миловић [Миловић 1965: 164, 169, 233], који је вратио у посљедњем примјеру апостроф из Стојковићева издања (оним'). 
У једнотомном Рјечнику [уз пјесничка дјела П. П. Његоша] првим примјером из Шћепана Малог илуструје се ријеч „тѐлйш (тј. те лиш) прил. нарочито” [СтевАновић-Бошковић 1954/1957: 217].

И све би то било разумљиво да у другом Стевановићевом издању није враћено растављено писање, али само у првом примјеру: те лиш оним што код куће чамју, (IV 35) [С тев Анови и 1967: 135], у трећем издању растављене су компоненте и у другом примјеру: те лиш оном ко га чуо није. (IV 116) [CтЕв Анови 1974: 138]. У трећем примјеру остало је састављено писање, у свим издањима: телиш оним који су одрасли (V 301) [Стев Анови и 1967/1974: 187].

Варијантност је одражена и у двотомном Речнику Његошева језика: „,т̀лиш (и те лйш) прил. нарочито, особито" [С тев Анови һ и др. 1983 II: 379], па се прво наводи трећи примјер из Шћепана Малог, написан састављено, а онда прва два примјера, растављено написана. Лексикографи су се служили четвртим издањем Целокупних дела [СтевАновић 1975: 187], а оно је фототипија трећег издања.

Како се објашњава ова неуједначеност? Једноставно: коректори су у другом издању спјева раставили компоненте у првом примјеру, а у трећем издању и у другом; лексикографи, коаутори Стевановићеви, како би убрзали рад на Речнику, нису увијек ни консултовали Стевановића, у овом и у бројним другим случајевима.

Растављено писање, досљедно, примјењују приређивачи у XXI вијеку; прије нас то је учинио Александар Младеновић: те лиш оним што код куће чамју, (2604); те лиш оном ко га чуо није. (2685); те лиш оним који су одрасли (3782) [МлАдЕНовић 2007: 160, 164, 217].

Ако је питање текстолоши разјашњено, није лексикографски. Двокомпонентна граматичка ријеч тё лӥш састоји се од рјечце тё у значењу ‘и то’, која је дијалектизам, и прилога лӥш у значењу 'само', који је русизам. У руском језику ријеч лишь понаша се као рјечца, која има и везничку употребу, и тада је карактерише побочни акценат, и као прилог, и тада је акценат главни. Другим ријечима, у погледу припадности врстама ријечи заузима прелазну позицију.

Рјечца тё у значењу ‘и то’, која је посвједочена у Његошевом језику, има (ослабљен, побочни) акценат, и на њу се не преноси акценат сљедеће ријечи. Дужина на другој компоненти у једнотомном рјечнику реконструисана је због претпоставке да је она настала скраћивањем од дијалекатског облика у изразима типа лимее Ма̂рка. А то лимше је архаични облик номинатива једнине мушког рода неодређеног вида некадашњег партиципа радног садашњег времена од глагола ли́шити.

У сва три контекста граматичка ријеч тё лӥш, с побочним акцентом на обје компоненте, везује се за облик показне замјенице онај, с главним акцен- 
том. Те три компоненте образују јединствену, али сложену фонетску ријеч: тё^лйш^о̀но̄м, тё^лйш^

$4^{\circ}$ Рјечца за наглашавање тё, у значењу 'и то’, употребљава се и самостално, на примјер у 289. стиху:

$$
\begin{aligned}
& \text { Сјутра̀да̄н ми коња изведоше, } \\
& \text { силна ха̀та ка̂ горскога дива, } \\
& \text { некована и необјахана, } \\
& \text { те Халата А̀рслановић-а̀ге. } \\
& \text { [ШМ 286-289], }
\end{aligned}
$$

а у комбинацији с прилогом лӥш, као шзо смо видјели - у збирном значењу 'и то само'.

(3) У 1921. стиху примјењујемо растављено писање копулативног облика нй(j)e испред придјева криิв:

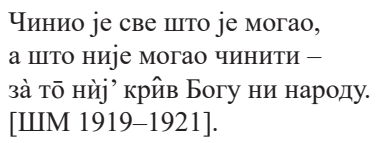

У већини издања примијењено је растављено писање: За то не крив Богу ни народу, [Столковић 1851: 92; Јовановићи 1881: 78; Вушовић 1935: 211 (III 237)]; с малим словом на почетку стиха [РешетАр 1926: 256; СтевАнови 1952: 100 (облик богу пише с малим словом); НЕдић 1964: 84 (и он облик богу пише с малим словом); Милови 1965: 123; МлАдЕнови ъ 2007: 125 (1956)]. У свим овим издањима прва компонента је представљена као рјечца не.

Драгутин Костић спаја рјечцу с придјевом, па она постаје префикс |не|: За то некрив Богу ни народу. [Костић 1902: 108 (1956)].


ријечи (неслоговно е означили смо графемом ј' с постпозитивним апострофом).

Претпостављамо да је у рукопису стајало ніе, па је Андрија Стојковић, да би остварио изосилабизам (овдје четири слога у првом полустиху), изоставио десетеричко i.

4. Растављено се пишу дво- и трокомпонентни везници с рјечцом ли у своме саставу.

(1) Везник то ли посвједочен је у стиховима 1217. и 1240:

Причај пашо, је ли ѝ Бо̄г дао, ал се чувај добро бѐспутице јер је ко̀д на̄с труิдно и прётруิдно 
путом ходит, тоि ли бѐспутицо̄м.

[ШМ 1214-1217];



У првом издању компоненте везника одштампане су растављено: Путом ходит', то ли беспутицом. [Столкови т 1851: 62]; То ли да смо Цару за дивана, [Столкови и 1851: 63]. То значи да је питање вербализације текста у наведеним стиховима ријешио већ Андрија Стојковић у своме издању. Растављено писање примијењено је у наредна три издања [ЈовАновићи 1880: 53, 54; Костић 1902: 71, 72; Решетар 1926: 231 (х 2)].

Састављено писање први је примијенио Данило Вушовић: Путом ходит, толи беспутицом. [Вушов и 1935: 190 (İ̀ 373)]; Толи да смо цару за дивана. [Вушовић 1935: 191 (II 396)], а настављено је у послијератним издањима [Стевановић 1952: 67, 68, исто у Недић 1964: 58 (х 2), Миловић 1965: 84, 85; МлАДЕНОвИЋ 2007: 86, 87 (1250, 1273)].

Састављено писање овог двокомпонентног везника, између свега осталог, условљава погрешан изговор, који нису избјегли ни лексикографи. У једнотомном Рјечнику [уз пјесничка дјела П. П. Његоша] једним примјером, али не из Шћепана Малог, илуструје се ријеч „тӧли свез. покр. акамоли” [Стевановић-Бошковић 1954/1957: 219]. Примјер је из Нове пјесне ирногорске о војни Русах и Тураках (стих 344), али је индикативно да је Радован Лалић у њему претходне године примијенио адекватно, р а с т а в љ е н о писање: солдат прости, то ли који виши; [ЛАлић и др. 1953: 23]. Од другог издања вербализација је измијењена: солдат прости, толи који виши; [ЛАли т 1967а: 23]. - У двотомном Речнику Његошева језика додато је још пет потврда, међу њима су и обје из Шћепана Малог, а уз нетачни акценат преузет из једнотомника додат је као алтернатива и тачни акценат: „тӧли и толли везн. $a$ камоли, а где, некмоли; исп. а толи” [СтевАновић и др. 1983 II: 387], али је остало састављено писање.

Двокомпонентни везник то ли посвједочен је и у Лучи микрокозма, али је он и у првом издању одштампан растављено: То ли (с. 45):

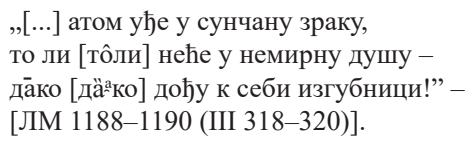

У критичком издању Луче истакли смо да је двокомпонентни везник $m \hat{o}$ ли данас архаичан и да растављено писање не само да одговара његовој ствар- 
ној структури и поријеклу него и сугерише тачан изговор. Облици показне замјенице, па и беспредлошки акузатив средњег рода $m \hat{o}$, граматикализацијом су прелазили у везнике. Њему је придодата рјечца ли, па је добијена двокомпонентна структура везничког типа [МАРо јеви һ 2016: 541-542].

(2) Везник а тоि ли има једну потврду, у 1752. стиху:

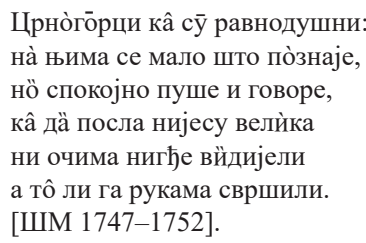

У првом издању проклитика је написана растављено од замјеничког облика, а енклитика састављено: А толи га рукама свршили. [Столкови 1851: 85]. Свога претходника исправио је приређивач издања браће Јовановића (и тиме ријешио питање вербализације текста у наведеном стиху): А то ли га рукама свршили. [Јов Анови и 1881: 72]. Растављено писање, и проклитике и енклитике, примијењено је и у наредна два издања [Костић 1902: 100 (1787); Решет ар 1926: 250 (III 68)].

Састављено писање енклитике први је примијенио, не рачунајући прво издање, Данило Вушовић: А толи га рукама свршили. [Вушовић 1935: 207 (III 68)]. Такво писање налазимо у каснијим издањима (с малим словом на почетку стиха) [Стевановић 1952: 93; Недић 1964: 78; Миловић 1965: 115; МлАденови ъ 2007: 116 (1787)] и у Речнику Његошева језика, овога пута само с погрешним акцентом: а тӧли в. а кӓмоли [С тевАнов и и и др. 1983 I: 2].

Растављено писање враћено је у нашем основном издању с обиљеженим (тачним) акцентом: а тоิ ли га рукама свршили [МАР о Ев и Ћ 2018: 358 (1752)].

(3) Везник а кӓмо ли употријебљен је у четири контекста (у 125, 863, 1917. и 2192. стиху):

смије ви се небо под којим сте, смије ви се мјесто на коิму сте а кӓмо ли ва̂с љу́бе̄ће̄ срце, па јошт срце вашега владике! [ШМ 123-126];

Давно бисмо тебе поздравили, ал не смјесмо (срамота је крити): пред твојом се силом земља тресе а кӓмо ли [мй] шака горштака̄ ја́мнйм нам се ругати нећете. [ШM 860-864]; 


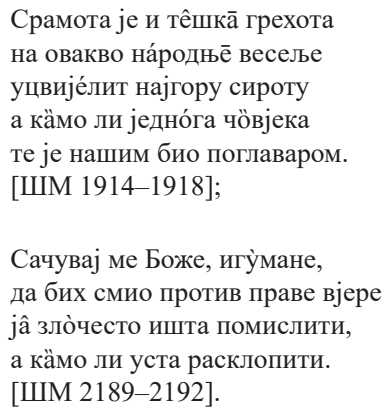

У првом издању везник је оштампан на три различита начина. У првом примјеру примијењено је растављено писање: А камо ли вас љубеће срце. [Столковић 1851: 14]. У другом примјеру проклитика је састављена са замјеничким прилогом, а енклитика је написана растављено: Акамо ли шака горштаках, [Столкови ъ 1851: 46] (један слог у другом полустиху недостаје). У трећем и четвртом примјеру проклитика је написана растављено од замјеничког прилога, а енклитика састављено: А камоли једнога човјека, [Сто јкови $\mathrm{h}$ 1851: 92]; А камоли уста расклопити. [Столковић 1851: 104].

У издању браће Јовановића, у свесци 5. Народне библиотеке, која је изашла у децембру 1880. године, задржано је растављено писање у првом примјеру (само што се стих завршава запетом) [Јов Ановићи 1880: 15] и исправљена је вербализација текста у другом примјеру: А камо ли чашица горштака - [ЈовАновићи 1880: 40]. Приређивач је васпоставио и недостајући слог у десетерцу само што су словослагачи пермутовали слова у првој именици - „чашица” умјесто шачица. У свесци 7. Народне библиотеке, која је изашла у јануару 1881. године, завршено је друго издање Шћепана Малог. У њој су исправљена преостала два стиха: А камо ли једнога човјека, [ЈовАновићи 1881: 77]; А камо ли уста расклопити. [ЈовАновићи 1881: 87]. Другим ријечима, са овим издањем ријешено је питање вербализације текста у везницима с компонентом ли.

Правилна вербализација текста примијењена је и у трећем издању, али је десетерац остао са девет слогова - версолошки је учињен корак уназад: А камо ли шака горштаках. [Кости ъ 1902: 53 (896)]. - Ни каснији приређивачи нису поправљали десетерац, али су мијењали вербализацију текста: Милан Решетар је прикључио енклитику, рјечцу ли претходној компоненти: а камоли шака горштаках - [Решет Ар 1926: 218 (II 19)], а Данило Вушовић и проклитику: Акамоли шака горштаках - [Вушови и 1935: 180], што прихвата и Михаило Стевановић, али само у првом издању: акамоли шака горштаках - [СтевАновић 1952: 51] (од другог издања пише а камоли, као Решетар, у складу с правописом из 1960. године, у чијем је састављању активно уче- 
ствовао). Владан Недић и Јевто Миловић су се прије Стевановића вратили на Решетареву вербализацију (почињући стих малим словом, како је и Решетар био одредио, али га коректори нису разумјели) [НЕди ћ 1964: 44; Милови Ћ 1965: 63]; Миловићеве текстологије се држи и Александар Младеновић [МлАДЕНОвИЋ 2007: 67 (896)].

Из свега наведеног слиједи да је текстологија 863. стиха Шћепана Малог превилно ријешена само у два издања, у издању браће Јовановића на један: а камо ли шачица горштака - [Ј о в Ано в и ћи 1880: 40] (исправљамо штампарску грешку), а у нашем основном издању на други начин: а кӓмо ли [мй] шака горштака̄ - [МАРо Еви и 2018: 323].

Рјешење које је примијенио Ђорђе Поповић-Даничар, који је вјероватно приређивао текст другог издања, било би сасвим у реду да у првом издању не пише: шака, а то значи да је тако писало и у Његошевом рукопису. Деминутив шачица није потврђен у Његошевом језику, а његова творбена база, основна именица шака, има више потврда, међу њима још три у самом Шћепану Малом, од којих је интертекстуално важна она из 2746. стиха:

\footnotetext{
Ми смо шака малѐна народа, Богу хва́ла, ӧпйта свободом да нам није јошт ове пјаности, давно бисмо ѝ мй упанули, ка сви други, у ђаво̀љӯ тӧрбу, [ШM 2746-2750].
}

С друге стране, у дилеми између аблативног генитива нас и субјекатског номинатива $м и$ опредјељујемо се за номинатив подстакнути интертекстуалном паралелом са 1236. стихом спјева (а и са другим примјерима из Његошевог језика):

Куд би вӥше̄ бруке и погрде
на свије́ту бйјело̄ме било
него да се мй пе́т-шест стӓрчӣна̄,
невјештијех скитати, кренемо?
[ШМ 1234-1237].

(4) Растављено се пише веза облика некадашњег 3. лица једнине императива у оптативном значењу бӱд $>$ > бӱд с постпозитивном рјечцом ли, у значењу 'ако', која у Шћепану Малом има двије потврде: ма бӱд ли сам ја, игумне, слијеп, [ШМ 112]; Бӱд ли мисле за мир Црно̀горци, [ШМ 954]. У оба примјера растављено писање примијењено је и у првом издању: Ма буд' ли сам ја игумне слијеп [Столков и 1851: 13]; Буд’ ли мисле за мир Црногорци, [Сто јкови ъ 1851: 50, уп. с. 184]. У другом издању примијењено је исто текстолошко рјешење у првом примјеру: буд' ли [ЈовАновићи 1880: 14], док у другом није исправљена штампарска грешка првог издања (коју је Стојковић исправио на 
крају књиге): Чуд’ ли [Јов Анови ии 1880: 43]. Растављено писање с апострофом налазимо у наредним издањима и у другом примјеру: Буд' ли [Кости 1902: 14 (114), 57 (987); Решетар 1926: 190 (I 116), 221 (II 110); Вушовй 1935: 158 (I 114), 182 (II 110)]. У првом издању Михаила Стевановића у другом примјеру је одштампано састављно: Буд’ли [СтевАновић 1952: 55 (II 110)], што је задржано и у наредним издањима (с. 58). Ову очигледну штампарску грешку понавља Владан Недић [Неди ћ 1964: 47 (и у другом издању, с. 48)], али не и два наредна приређивача - они су и у другој потврди ријечи раставили: Буд’ ли [Миловић 1965: 68; МлАденовић 2007: 72 (987)]. Занимљиво је да су лексикографи штампарску грешку „канонизовали”: они су, у одредници бу̀ди, везник (појачан рјечцом ли) у другом примјеру навели састављено, а у првом - растављено; варијанту буди ли из Горског вијенца растављено, а из Огледала србског - састављено [Стевановић и др. 1983 I: 55]. У основном издању ми смо претходнике кориговали утолико што смо изоставили апостроф и додали акценат [МАРОјЕви Ћ 2018: 294, 327].

Решетар је своје издање припремао према издању браће Јовановића, које није имало нумерацију стихова, па се у првом деиствију забројао: број 75 ставио је поред стварног 73. стиха, па се грешка наставља; код нас има два стиха мање јер ми у стихове нисмо убројали понављање дјелова претходног стиха на почетку двију реплика (као ни касније „разговор” Шћепана и папагала). Костић и Младеновић дају нумерацију у континуитету, а не по чиновима, као и ми, али су они, као и њихови претходници, шеснастерце час бројали као два, час као један стих, па у њиховим издањима има 4105 односно 4104 стиха (а у нашем 4019, од којих су 150 шеснаестерци). А разлика у нумерацији између Костићевог и Младеновићевог издања појавила се у 2620. стиху - обраћање књаза Долгорукова на руском својима Младеновић није урачунао, као ни ми (код нас је то проза између стихова 2546. и 3547).

Иу Горском вијениу је посвједочен облик у којем је некадашњи императив трећег лица једнине буди попримио значење условног везника 'ако': Буди ли се ти та̀ко̄ проричеш, [ГВ 1501]. На њега је обратио пажњу Данило Вушовић сматрајући „да оптативни облик буди, као и у дијалекту, узима каткад у зависним реченицама значење свезе (макар, кад, пошто)" [Вушови ъ 1930": 165; уп. Вушови $1930^{\sigma}$ : 73] и наводећи међу примјерима и овај, из 1501. стиха Горског вијенца. Ми бисмо ипак дали предност тумачењу које се даје у Речнику Његошева језика, гдје се наведеним стихом илуструје прво значење ријечи: бу̀ди везн. (појачан речцом ли) 1. погодбени: ако, кад (већ) [СтевАновић и др. 1983 I: 55]. И Свет. Вуловић је дао сличну интерпретацију: „Буди ли = кад, кад већ. Дакле: кад им ти тако проричеш, а да ли они сами што брину, боје ли се кога?" [Вулови и 1886: 38 (најприје објављено у: Самоуправа, Београд, 27. јула 1886, I, бр. 73, с. 1)]. У 1501. стиху Горског вијенща имамо, дакле, везу 
некадашњег императива буди (у значењу условног везника) са рјечцом ли: бӱди ли (се ти тако проричеш), као и у наведена два стиха Шћепана Малог.

У својим издањима Никола Банашевић везник и рјечцу пише састављено: Будили се ти тако проричеш, [БАНАшЕв Иъ 1973: 73], а тако чине у аналогним случајевима приређивачи других Његошевих дјела, што је одражено и међу примјерима у Речнику Његошева језика. Састављено писање није оправдано: енклитика ли чува значење упитне рјечце, па је треба одвајати од везника буди.

НАПОМЕНЕ.

1. За растављено писање (за раздвајање рјечце ли од императивног облика), као аргумент се могу узети стихови: будди ондје ђе су јачи Турци. [ШМ 1685, Буди (с. 82)]; бӱди оно што је сваком јавно: [ШМ 2194, Буди (с. 104)], који свједоче да рјечца ли није била обавезна компонента конструкције. У ова два стиха императивни облик има значење 'макар'.

2. У примјеру: Да́јбуди ви ја не требам ништа. [ШМ 1979] императивни облик буди срастао је с императивним обликом дај са заједничким значењем 'ваљда', али у том случају ми, за разлику од првог издања: Дај буди (с. 94), реконструишемо састављено писање; то је међутим, предмет разматрања у раду Маројевић 20216.

5. Растављамо рјечцу год од упитно-односне замјеничке ријечи (оне формирају један тип аналитичких неодређених замјеница), а састављено постфикс |год|, али о томе види у раду Маројевић 2021в.

6. Растављено пишемо везу саставног везника $u$ и условног везника аัко, при чему акценат остаје на компоненти ӓко [види даље т. (1)], а састављено везник за допуштање иेако, у коме се акценат обавезно преноси на прву компоненту [види даље т. 2]. Паралеле ради, из Горског вијенца наводимо примјер везе саставног везника $u$ и условног везника ӓко [види даље т. 3] те супротног везника $a$ и условног везника ӓко [види даље т. 4].

(1) Веза саставног везника $u$ и условног ӓко посвједочена је у првом такту (првом полустиху) 37. стиха и у другом такту 2764. стиха, па у њима треба примијенити растављено писање:

\footnotetext{
Ако ишта очи по̀ма̄гајӯ

и ако је игђе ишта било, чисто знади оче-игумане цар је руски данас на Цетињу! [ШМ 36-39];

Сва је Турска данас у Европу ка стог сухе сламе ал сијена не требује него смјёла̄ ру́ка
} 
да үิ њ метне ватру с једне стране

да се цио пепелом прометне,

а та ру́ка ви можете бити

ако знасте и ако шћедосте.

[ШM 2758-2764].

У првом издању примијењено је растављено писање: И ако (с. 10), и ако (с. 130), али то није релевантно: по тадашњем правописном узусу двокомпонентни везник се не разликује у писању од везника за допуштање йако. Зато је од значаја погледати издања у којима се овај други пише састављено. Растављено писање примјењује Милан Решетар: И ако је игђе ишта било, [Решет aP 1926: 188 (I 38)]; Ако знасте и ако шћедосте. [Решетар 1926: 289 (IV 268)], а слиједе га сви каснији приређивачи.

(2) Везник за допуштање ѝако представљен је у првом такту (првом полустиху) 2198. и 3870 . стиха:
а и мјесец рђав свједок није, иако се с плачем прошѐтује - нӧ ми пукне срце ӧд жалости кад погледам опаку судбину која паде на нашем народу.
[ШМ 2197-2201];
Које драิго лӓко имат није, ма јест лӓкшӗ једно од дрӱго̄га, иако се једно с другим веже. [ШМ 3868-3870].

У првом издању примијењено је растављено писање и у овом значењу: И ако [Столкови ъ 1851: 104, 177]. Исту вербализацију текста налазимо у наредна два издања [ЈовАновићи 1881: 97, 146; Костић 1902: 123 (2249), 205 (3944)].

Састављено писање уводи Милан Решетар: иако се с плачем прошетује. [Решет AP 1926: 266 (III 530)]; иако се једно с другим веже. [РешетАР 1926: 328 (V 462)], а слиједе га сви каснији приређивачи.

Везник иेако у првом издању Луче микрокозма одштампан је растављено: И ако (с. 64, 75), а и у каснијим издањима остаје таква вербализација текста jep је то налагала (неоправдано) правописна норма. У новијим издањима везник се пише састављено: ѝако је њихова стихија [ЛМ 1724 (V 304)]; и цар Земље, йако у ропству. [ЛМ 2020 (VI 90)]. Везник иेако треба разликовати од двокомпонентне граматичке ријечи (комбинације рјечце за појачавање и везника) $u$ ӓко, али она није са тим распоредом компоненти потврђена у Лучи; јесте у другом распореду ӓко $u$ : јер он опет, ако и забуњен, [ЛМ 2018 (VI 88)].

(3) Састављено или растављено писање није у текстолошким истраживањима пуко ортографско питање: оно је истовремено и прозодијско и 
семантичко. Да ли ћемо у 1019. стиху Горског вијенца: И ако є земля поузана, [МедАковић 1847: 39] писати $и$ ако или иако, од тога зависи како ћемо наведени сегмент читати - [иӓко] или [йако] и које ћемо значење (уопштено или конкретно) стиховима приписати. Ако се опредијелимо за састављено писање, као што је то учинио Данило Вушовић [Вушови 1935: 34], онда ћемо иेако интерпретирати као допусни везник, а стих ће добити конкретно значење: Иако је [наша] земља поузана... Ако оставимо растављено, као што је то учинио Милан Решетар [Решет ар 1890: 142; Решет ар 1926: 39], стихови ће добити уопштено значење ('и кад је нека земља омања'), а у зависној реченици у инверзији разликоваћемо рјечцу $u$ за појачавање и условни везник ӓко:

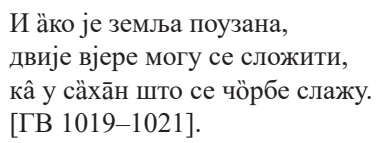

Граматички гледано, обје интерпретације су подједнако могуће. За Решетареву вербализацију текста опредјељујемо се из два разлога: $1^{\circ}$ и кад мисле на конкретну ситуацију, јунаци Горског вијенца се по правилу служе уопштеним констатацијама и гномским стилом; $2^{\circ}$ прихватањем другог тумачења не мијења се ортографија изворног издања. Овај други аргумент нема исти значај као први. Поред тога, није битно што је у оригиналном издању написано растављено, важно је да у првом издању није написано састављено, као ни у пјесниковом аутографу: и ако є земля поузана - [ВГ: л. 11 об.]. Наиме, у првом издању се пише растављено: И ако [Медаковић 1847: 71, 105] и у случају кад је посвједочен несумњиви допусни везник иेако: Иако си турска придворица, [ГВ 1799]; иако је лијепо вријеме, - [ГВ 2553].

\section{НАПОМЕНА.}

У издању Његошевог рукописа Вијенац горски које је објавио краљ Александар Карађорђевић 1931. године нису били означени листови. У факсимилу који је, у склопу јубиларног издања дјела, објавила Црногорска академија наука и умјетности 1985. године, листови су обиљежени, али је испуштен први лист на коме је наслов (и претходне прецртане двије варијанте наслова спјева, док је полеђина празна), тако да је 1019. стих стварно на листу 12 об.

(4) Да ли ћемо у 2150. стиху Горског вијенца: Ако намъ с міо али свойта, [МедАкови 1847: 88] писати условни везник ако (дакле састављено) или супротни везник $a$ и номинатив замјенице ко (дакле растављено), то зависи од значења које наведеном сегменту приписујемо. Милан Решетар, а за њим и бројни други приређивачи, остао је код ортографије првог издања: ако нам је мио али својта, [Решет АР 1890: 195]. Јевто Миловић је, међутим, изнио хипотезу да сегмент Ако из првог издања не представља један везник 
већ двије ријечи, везник $a$ и замјеницу ко, те да ако „треба раздвојити и онда се тек добија прави смисао стихова" [Milović 1965: 65; цит. по Миловит 1983: 366]. Неки приређивачи су његово мишљење прихватили, па 2150. стих доносе у сљедећем ортографском и граматичком лику: а ко нам је мио али својта, [БАНАШЕвИЋ 1973: 105] и др.

Јевту Миловићу ипак не припада примат у растављеном писању наведене ријечи. Лука Грђић-Бјелокосић у напомени уз одјељак „Вјештица” у књизи Из народа и о народу (књ. II, Мостар 1897, стр. 50) цитира (нетачно) Његошеве стихове пишући анализирану ријеч растављено: „Зла мрзнијем чинит' не моремо, / А ко нам је мио или својта, / Траг по трагу њему ископамо”, на шта је указао Ристо Ј. Драгићевић оправдано сумњајући у исправност таквог поступка: „Ту је, пак, ријеч раставио још крајем прошлога вијека Лука Грђић-Бјелокосић [...], а и питање је да ли је то правилно" [ДРАгићевић 1975: 1521].

Михаило Стевановић сматра да је Јевто Миловић „скренуо пажњу на погрешно преношење ортографске грешке из I издања Вијенца, у којем је заједничким писањем везника $a$ с односно-упитном заменицом ко промењен смисао и однос посебних реченица у сложеној [...], од којих је друга, која почиње са $a$ $\kappa o$, независна супротна реченица у односу на непосредно претходну. Тако их је песник свакако замишљао, јер цела мисао тек тако схваћених ових стихова има свој смисао. Њом се хтело рећи: да траг по трагу ископају ономе ко им је мио или својта. Заменица (ко) ту, дакле, мора постојати. Спајањем те заменице с непосредно претходним $а$ добија се везник ако, а неопходне заменице нестаје. Онда однос реченица постаје зависан, и из таквог односа произилази смисао реченица да не могу учинити зла мрзноме ако им је мио или својта. А то је бесмислица, јер мрзни не може бити мио, макар био и својта. А осим тога, трећи сад наведени стих у томе случају висио би сам за себе, одвојен од два претходна" [СтевАновић 1976: 116; цит. по СтевАновић 1990: 181]. Ово тумачење (цитирајући и парафразирајући при том свог претходника, али не наводећи библиографски податак) прихвата Бранислав Остојић: »Правописна грешка из првог издања Горског вијенца у вези са писањем везника $a$ и замјенице ко $[\ldots]$ преносила се из издања у издање Горског вијенца. [...] Такво писање је уносило забуну прије свега у језичко и семантичко тумачење три узастопна стиха и усмјеравало је семантичку вриједност стиха у погрешном смјеру до бесмислице. [...] При таквој синтаксичко-семантичкој вези наведена два стиха значе „да не могу чинити зло мрзноме ако им је мио или својта”. Међутим, морамо констатовати стварну истину да „мрзни не може бити мио па макар био и својта". И то је она бесмислица до које нас води овако успостављени однос реченица преко везника ако. Трећи стих који се при таквом ортографском решењу овога везника не веже тјешње са стихом у којем не функционише односно-упитна замјеница ко, него везник ако остаје по страни да „виси” сам за себе« [Остолић 1996: 207-208; уп. Остолић 1997: 199-200]. 
Мишљење Јевта М. Миловића те захтјев Александра Младеновића: „овај спојено одштампани пример треба раздвојити” [МлАденовић 1996: 33] - сувише су аподиктични. Смисао имају стихови, али један смисао, и кад се пође од условног везника ако, и имају смисао, али други, кад се пође од супротног везника $a$ и замјенице ко. Обје интерпретације, граматички гледано, подједнако су могуће. Миловићево тумачење било би прихватљивије кад би стих значио да вјештице с в акоме ко им је „мио али својта” траг по трагу ископају. Али он то сигурно не значи. Зато се ми и опредјељујемо за класичну вербализацију текста (само што умјесто запете на крају 2150. стиха стављамо повлаку), наводећи за њу два аргумента: $1^{\circ}$ вјештице се договарају какво ће зло учинити коме:

договоре кријући чинимо какво ћемо зло учинит ко́ме;

[ГВ 2144-2145],

али увијек то не могу да остваре: ако им је т ај мрзан - не могу му чинити зла, а ако им је о н мио или својта - траг по трагу његов ископају; $2^{\circ}$ прихватањем овог тумачења не мијења се ортографија изворног издања, тј. не мора се реконструисати штампарска грешка у првом издању. У складу са новим, изворним читањем текста Горског вијения и новим, изворним тумачењем Његошевог десетерца, по којем у Његошевом пјесничком тексту налазимо бројне и разноврсне типове фонетских дифтонга који не нарушавају десетосложну силабичку структуру него је напротив чине ритмички разноврснијом, ми у првом полустиху 2150. стиха - на граници супротног везника $a$ и условног везника ако:

\footnotetext{
Зла мрзноме чинит не можемо,

а̄ко нам је [’ӓконамје] мио али својта -

траг по трагу његов ископамо.

[ГВ 2149-2151] -
}

алтернативно реконструишемо контракцију вокала, и то дифтоншки степен контракције: āко [äӓко] = а ако. Наравно, код овог алтернативног текстолошког рјешења морамо остати код тумачења да је у Његошевом стиху посвједочен везник ако, а не - како је то предложио Јевто М. Миловић - односна замјеница ко. Таквом тумачењу дајемо предност и иначе, тј. и ако не бисмо реконструисали контракцију вокала у проклизи (само што бисмо у том случају оставили тачку и запету на крају 2149. стиха, тј. интерпункцију бисмо прилагодили таквој интерпретацији). Треба још напоменути да стих Зла мрзноме чинит не можемо не значи: „зла не можемо чинити ономе који је омражен (ономе кога мрзе)" [МлАдЕнови ъ 1996: 232], него: не можемо чинити зло ономе кога ми (= вјештице) мрзимо, ако је нама (= вјештицама) мрзан (мисли се, наравно, на оног за кога су се вјештице претходно договориле да му учине какво зло), 
што уопште не значи да је он - омражен [види подробније у МАРојеви 2005: 879-882].

7. Поставља се дилема: да ли је у 962. стиху Шћепана Малог посвједочена веза прилога јёдна̄ко с рјечцом свё која није транспозицијом прешла у префикс, па их треба само писати растављено, као у Лучи микрокозма - свё јёдна̄ко [види даље т. (1)], или реченична конструкција коју чине субјекат свё (облик средњег рода замјенице који није граматикализацијом прешао у рјечцу нити транспозицијом у префикс) и предикат је јёдна̄ко чија је копула, након губљења интервокалског $j$, са замјеницом срасла у диверб свё, као у Горском вијенцу - свё 〈ј) је јёдна̄ко [види даље т. (2)]?

(1) У два стиха Луче микрокозма (1572. и 1795) посвједочена је комбинација рјечце свё и прилога јёдна̄ко:

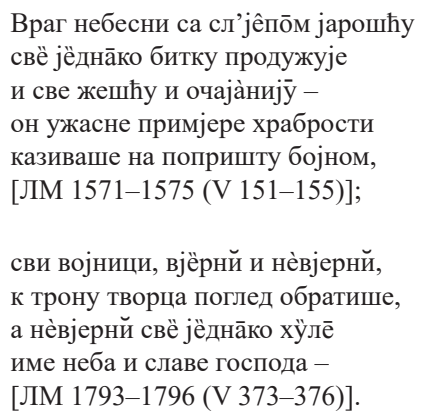

У акценатском издању израз свё јёдна̄ко у оба стиха снабдијевамо напоменом: метрички акценат на другој компоненти (прва је десемантизована, прешла у рјечцу). Замјеница (средњи род једнине) свё граматикализовала се, а граматикализација је подврста транспозиције у којој значењска ријеч губи лексичко (или упућивачко) значење и прелази у везник, предлог или рјечцу, овдје у рјечцу.

Растављено писање налазимо већ у првом издању: Све сднако (с. 59), све сднако (с. 66).

(2) Сличан, али суштински друкчији израз налазимо у Горском вијениу (у првим издањима изрази су хомографи).

На чуђење игумана Стефана - што је [Нова година] данас ошћела људима? - одговара владика Данило: Све сднако, тада али данасъ, / Вріеме ће своимъ токомъ ходит"! - / А ово су стари уредили. [МедАКовић 1847: 110]. Наведени стихови постављају пред текстолога три питања: $1^{\circ}$ ортографско: да ли треба писати растављено све једнако или састављено свеједнако; $2^{\circ}$ интерпункцијско: којим знацима треба обиљежити завршетак 2677. и 2678. стиха; $3^{\circ}$ прозодијско: да ли треба читати [свѐједна̄ко], [свё^јёдна̄ко] или [свё^^јёдна̄ко]. 
Милан Решетар је у издању Горског вијенща дао овакву ортографску и интерпункцијску интерпретацију реплике владике Данила (стихова 2677-2679):

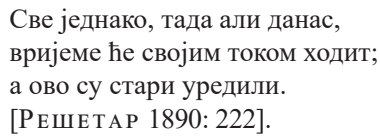

Оваква ортографија и интерпункција задржана је у првом издању Цјелокупних дјела П. П. Његоша [Бошковић-ЛАтковић 1952/1957: 127]. У другом издању Целокупних дела Петра Петровића Његоша [Бошкови и и др. 1967: 125] задржана је оваква интерпункција, али са састављеним писањем свеједнако, што је вјероватно редакторска интервенција усклађивања с новим правописом и с интерпретацијом у Рјечнику [уз пјесничка дјела П. П. Његоша]. Наведена интерпункција, међутим, није адекватна: њоме се истиче да је све једнако адвербијал у реченици која конституише 2678. стих (у смислу: вријеме ће свакако ходити својим током). Адекватна је интерпретација 2677. стиха као самосталне реченице (у смислу: све је једнако, [да ли је Нова година] тада или данас). То је осјетио већ Решетар, па је у издању Целокупних дела Петра Петровића Његоша [РЕшет АР 1926: 98] измијенио интерпункцију, ставивши двије тачке послије 2677 , а запету послије 2678 . стиха.

С нашом интерпретацијом облика свё [свёе $]=$ све је и са Решетаревом интерпункцијом из Сабраних дела, која нам се чини најадекватнијом (само што ми пишемо повлаку умјесто запете на цезури 2677. стиха), реплика владике Данила у критичком издању [види подробније у МАР оЈеви и 2005: 856-857] добија сљедећи облик:

\footnotetext{
Све̄ једнако [свёе јёдна̄ко] - тада али данас: вријеме ће својим током ходит, а ово су стари уредили.
}

[ГВ 2677-2679].

Овдје се у изговору остварује таутовокалски дифтонг између облика замјенице свё и копуле је након губљења интервокалског $j$ : Свё једнако [свё $\mathrm{j}$ `^^јёдна̄ко]. У основном издању стих је ортографски представљен на сљедећи начин: Свё јёдна̄ко - тада али данас: [ГВ 2677] с објашњењем у поговору [МАРојеви Ћ 2018: 260, 277].

У 2677. стиху Горског вијенца представљена је, дакле, реченична конструкција коју чине субјекат свё (облик средњег рода замјенице који није граматикализацијом прешао у рјечцу нити транспозицијом у префикс) и предикат је јёдна̄ко чија је копула, након губљења интервокалског $j$, са замјеницом

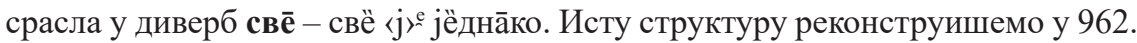
стиху Шћепана Малог: 


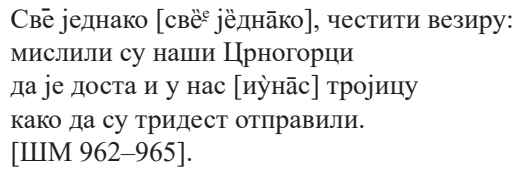

Овдје се у изговору, као и у Горском вијениу, остварује таутовокалски дифтонг између облика замјенице свё и копуле је након губљења интервокал-

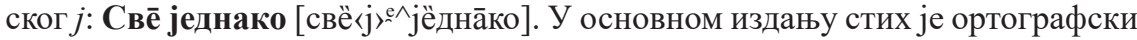
представљен на сљедећи начин: Све̄ јёдна̄ко, честити вёзӣру: [ШМ 962] с објашњењем у поговору [МАРојеви һ 2018: 327, 460].

Ни у једном од издања која су нашем претходила није указано на диверб (то би они обиљежили тзв. генитивним знаком или знаком за дугосилазни акценат све̂, који се раније нису ни диференцирали), али сви приређивачи примјењују растављено писање, које је представљено већ у првом издању: Све једнако честити Везиру! [Столковић 1851: 50]. У другом и наредним издањима поправљена је ортографија и интерпункција: Све једнако, честити везиру! [Јовановићи 1880: 44; Кости и 1902: 57 (995); Решетар 1926: 221 (II 118), исто у Вушов иъ 1935: 182 (исто у издању из 1936, с. 200)]. Михаило Стевановић замјењује узвичник тачком и запетом: Све једнако, честити везиру; [СтевАновић 1952: 55 (II 118), што није мијењано у наредним издањима, с. 59; исто у НЕдић 1964: 48, Миловић 1965: 68; МлАДЕНОви һ 2007: 72 (995)].

У једнотомном Рјечнику [уз пјесничка дјела П. П. Његоша] „ријеч” свѐједна̄ко прил. покр. свеједно [СтевАновић-Бошковић 1954 / 1957 : 189] илуструје се само примјером из Горског вијенща. У двотомном Речнику Његошева језика наводе се, у оквиру исте одреднице, „прилог” свѐједна̄ко и „прилог” свејѐдно у значењу “потпуно исто, сасвим једнако' [С тев Анови и др. 1983 II: 262], без стилске квалификације: први се илуструје наведеним примјером из Горског вијенца, и пише се састављено, а други примјером из Његошеве преписке, при том се у тому у коме су писма, сасвим оправдано, примјењује растављено писање (па га растављено цитирају и лексикографи): Хиљада или пет хиљада Црногораца да су погинули све једно бива - Црна Гора има простора. Лексикографска интерпретација примјера из Горског вијенца, као што смо показали, није ни прозодијски ни лексичко-граматички тачна. Употреба глаголског облика бива и растављено писање указују да се синтагма све једно није лексикализовала ни у другом примјеру. Другим ријечима, ни прилог * свејѐдно у Његошевом језику није потврђен (он би настао елипсом копуле у предикатској конструкцији свеједно [je]), него синтагма свё јѐдно: у Његошевом писму копула је изражена обликом бива.

8. Растављено пишемо, с једне стране, двокомпонентни саставни везник ӓл(u) $u$ и, с друге стране, комбинацију копуле је и рјечце ли с рјечцом $u$ у фразеологизму је ли и Бог дао. 
(1) Саставни (копулативни) везник ӓл(u) u, у значењу 'и', 'а и', 'али и', чије компоненте ми пишемо растављено, реконструишемо у 3435. стиху Шћепана Малог:
Тр̀пија је пӧхла̄пна нӓ дӯшу како мо̀ра на мла́до тијело, ӓл' и о̀на има́де 'ѐћима - прави разум с бистрима очима које ствари овога свијета чисто виде, а не кроз копрену. [ШМ 3433-3438],

у 44. стиху Луче микрокозма:

Нӧ врёмена̄ питателница ми
(окићена цвијетним временом,
о̀круњена сунча̀нім зра̀кама,
ӓл’ и вла̂се цвијетне плетући, [...])
[ЛМ 41-44 (Пролог)]

и у 33. стиху Горског вијенца:
A ја што̀ ћу, ӓл' и са ки́ме ћу: мало рука̄ - малена и снага, једна сламка међу вихорове, сирак тужни без нигђе никога! [ГВ 33-36].

У аутентичном изговору остварује се таутовокалски дифтонг између

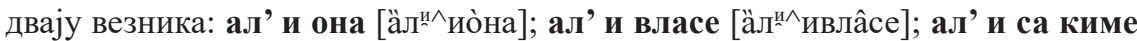
ћу [ӓл ${ }^{и \wedge}$ исаки́мећу]. Прво, неслоговно $u$ припада претходној, побочној фонетској ријечи, а друго, слоговно $u$ - наредној, главној фонетској ријечи, као њена проклитика.

У критичком издању Горског вијенца [види подробније у МАројеви и 2005: 407-408] подробно је описана граматичка хомонимија раставног (дисјунктивног) везника алиі, супротног (адверсативног) везника али (копулативног) везника али ${ }^{\mathrm{II}}$ и упитне рјечце $а л u^{\mathrm{IV}}$. И у текстологији Шћепана Малог примјењујемо правила која су тамо формулисана.

(2) Растављено се пише комбинација копуле је и рјечце ли с рјечцом $u$ у фразеологизму је ли и Бог дао, који у Шћепану Малом има двије потврде. У 1214. стиху он заузима други полустих, па силабичка структура није захтијевала сажимање његових компоненти: Причај пашо, је ли ѝ Бо̄г дао, [ШМ 1214]. У првом издању прве двије компоненте фразеологизма су састављено одштампане: Причај, Пашо, јели и Бог дао! [Столкови 1851: 62], па их треба само раставити, како је то учињено у другој потврди већ у првом издању: Је ли Бог да', имамо ли с киме, [Столкови и 1851: 127], али у њој треба, према 
првој потврди, васпоставити трећу компоненту, рјечцу $u$, а вокал у рјечци ли скратити до нивоа неслоговне компоненте дифтонга: (јё л’ ѝ Бо̄г да̄, има́мо ли с киме): [ШМ 2695]. На мјесту апострофа ми препоручујемо изговор неслоговног $u$, али се вокал може и потпуно изоставити.

9. Растављено се пише, с једне стране, везник нй односно нйт с глаголском енклитиком сам, и с друге стране, веза одричне рјечце ни (која није прерасла у префикс) с бројем један.

(1) Парни везни нит(u) представљен је у стиху: нит сам чуо, нити ћу је чути, [ШМ 2271], али у њему није било спорно растављено писање везника нӥт(u) и глаголске енклитике сам. На основу ове интертекстуалне паралеле ми смо и у стиху: Ни[т] сам знао, нити маิрйм знати - [ШМ 1618] примијенили растављено писање, што је обавезно, и васпоставили финални сугласник $m$ у везнику, што је факултативно.

У прва два издања везник и глаголска енклитика одштампани су састављено: Нисам знао нити марим знати, [Сто јкови 1851: 80; Јов Анови и 1881: 67]. У сљедећа два издања поправљена је интерпункција, али не и правопис: Нисам знао, нити марим знати; [Костић 1902: 93 (1652); Решетар 1926: 245 (İ̀ 775)].

Текстолошки проблем вербализације текста ријешио је Данило Вушовић: Ни сам знао, нити марим знати; [Вушо ви 1935: 202 (II 775)], с образложењем у Поговору: „Стих „Нисам знао нити марим знати (II 775)” исправљен је у: Ни сам знао... (тј. нити сам знао...) [...]« [Вушови и 1935: 656].

Михаило Стевановић, у првом издању у сарадњи с Радованом Лалићем, ставља и акценат на везнику нй: Нй сам знао, нити марим знати; [СтевАнови 1952: 86 (II 775)]. Ово текстолошко рјешење сасвим је у реду, али ми га дајемо само као алтернативно; интертекстуална паралела указује да је ту боље васпоставити и сугласник $m$, што је прије нас учинио Александар Младеновић: Ни[т'] сам знао, нити марим знати; [МлАденови и 2007: 109 (1652)]. (Ми везник нит овдје пишемо без апострофа, а с апострофом испред $u$ као знак да се у аутентичном изговору на његовом мјесту остварује неслоговно $u$ : нйт' има́мо мира ни[т] састанка [ШМ 3734].)

(2) Растављено се пише веза броја један с рјечцом ни која се није трансформисала у замјенички префикс (уз прозодијску реконструкцију) кад значи 'ни један једини'. Ова конструкција има три потврде у Горском вијениу: (а не бисте) ни јѐдну (хватали) [ГВ 195]; (неки један - то је ка) ни јѐдан [ГВ 644]; (и) ни јѐдан (није изван куће) [ГВ 1707].

Једна потврда конструкције ни јѐдна потврђена је и у Лучи микрокозма: (да) ни јѐдна (најмања частица) [ЛМ 1968 (VI 38)]. Значење броја ('ни 
једна једина') наглашава атрибут најмања. И у првом издању рјечца се пише растављено: ни сдна (с. 73).

Конструкцију ни један пишемо растављено, као и у првом издању: ни један (с. 52), и у Шћепану Малом, у јединој потврди (у 998. стиху):

позваћемо на договор к нама
по̀глава̄ре војске црногорске;
свй ће̄ нам се томе подру́гати -
доћ ни јѐдан ни за̀ везу не̂ће;
куд ће гӧре̄ ла̀же̄ од оваке?
[ШМ 995-999].

НАПОМЕНА.

Од рјечце ни и броја јѐан настала је одрична замјеница нйједан. То је некадашња веза броја с рјечцом која се трансформисала у одричну замјеницу с префиксом |нй|. У Горском вијениу одрична замјеница нйједан има три потврде, а пишемо је састављено: (није од њих) ниједно́zа (жива) [ГВ 1355]; (ту не бјеше) ниједно́zа (чойка) [ГВ 1518], осим кад предлог раздвоји њене компоненте: (нема тога) нй у једну (књигу) [ГВ 2179]. У Лучи микрокозма одрична замјеница нйједан с именицом дух реализује значење 'нико': (дух) нйједан (општег створитеља) [ЛМ 533 (І 333)]. Састављено писање ове замјенице примијењено је већ у првом издању: нісданъ (с. 22). У Шћепану Малом замјеница нйједан посвједочена је само с предлогом, који раздваја њене компоненте: нй за једно блаิго на свијету. [ШМ 1150], па се пише растављено већ у првом издању: Ни за једно (с. 59).

10. Растављено се пишу везе именица и замјеница с енклитикама: ама̀нат $m и$ [види даље т. (1)], она̀ко̄ га [види даље т. (2)] и узвичним рјечцама у проклизи: ё тоิ [види даље т. (3)], ö Кану́ни [види даље т. (4)].

(1) Растављено се пише веза именице ама̀нат с енклитичким дативом личне замјенице 2. лица једнине $m и$.

У првом издању Шћепана Малог приређивач је, оправдано, раздвојио енклитику и васпоставио финално т именице, али је, неоправдано, именицу ама̀нат (ген. ама̀нта), с непостојаним $a$, замијенио варијантом са сталним $e$, у обје потврде: аманет ти (с. 11), аманет’ ти (с. 36). Ми смо, најприје у основном издању, вратили аутентични облик именици у заклетви као фразеолошком жанру: У разлог се мало, ама̀нат ти - [ШМ 45]; Причај Сма̂jо, ама̀нат ти бо̀ж’јй, [ШМ 684].

Овај други примјер показује да је пуни облик заклетве гласио аманат ти божији у значењу 'тако ти Бога'. Оправданост наше корекције првог издања потврђује посвједоченост именице у генитиву: рад ама̀нта доша сам бо̀ж'је̄га - [ШМ 3269]. 
Ми овдје, у критичком (и у акценатском) издању, текстологију анализиране заклетве као етнокултурног жанра завршавамо тако што графему $\mathbf{e}$ првог издања замјењујемо са а уз уједначавање акцента, у три потврде; једна је у номинативу: ама̀нат је бо̀ж’јй ствар вёлика̄. [ШМ 3240], друга у акузативу без предлога: Шћепан ми је ама̀нат предао [ШМ 3242], трећа у акузативу с предлогом на: на ама̀нат ка̂ осталу стоку. [ШМ 1030]. Замијењени вокал у критичком и акценатском издању стављамо у квадратну заграду: аман[а]т.

Да је у Његошевом идиолекту постојала и именица ама́нет у значењу 'светиња' потврђује ауторизовани рукопис и прве публикације пјесме Поздрав србском роду: те ама́нет и општу светињу, [ПСР 61] и сачувани фрагмент рукописа Шћепана Малог: и ама́нет наше народности; [ШМ 15], којима прикључујемо још три примјера из спјева: царска ријеч - ама́нет највиши, [ШМ 2622]; на ама́нет и светињу своју? [ШМ 2975]; Чувају га ка̂ ама́нет неки, [ШМ 3505]. Примјере смо сад прозодијски уједначили у корист дугоузлазног акцента.

У Горском вијениу веза именице ама̀нат с енклитичким дативом личне замјенице 2. лица једнине $m и$ писана је и штампана фонетски упрошћено и састављено, и у првом и у свим каснијим издањима прије наших; ми смо први раздвојили енклитику и реконструисали прво т, на крају именице, ортографски: амана[т] ти, прозодијски (у квадратној загради): ама̀нат:и [М А Р О Јв и Ћ 2005: 857-859].

Сегмент аманати из првог издања Горског вијенща: Ђе га купи ага, аманати? [МедАковић 1847: 39], и у рукопису: аманати [ВГ: л. 11 об.]; А бъше ли какавъ, аманати? [МедАКови 1847: 63]; Аманати ђе научи тако? [МедАковић 1847: 84]; Аманати, ненаіеди се! [МедАковић 1847: 85]; Исприча ни штогодъ аманати! [МедАКовић 1847: 92]; Ђе си быо данасъ аманати, [МЕдАковић 1847: 103] у већини издања третира се као једна лексичка јединица. Као једну лексичку јединицу израз наводи и Божидар Ковачевић, али га тумачи на сљедећи начин: „аманати, вере ти” [Ков чеви 1940: 78]. Владан Недић наведени сегмент, међутим, разбија на двије лексичке јединице, на примјер: Ђе га купи, ага, амана ти? [Неди ъ 1964: 170]. Кад би Ковачевићево тумачење било тачно, одговарала би му Недићева вербализација текста. У том случају облик ама́на био би генитив именице àмāн 'вјера'. Иначе, именица а̀ма̄н у значењу 'милост’ потврђена је у Шћепану Малом: један другом не чини ама́на, [ШМ 3741].

Наше рашчлањивање текста и издвајање предикативног фразеологизма аманат ти потврђују фразеологизми аманат ви, аманат ми у стиховима: Пуштите их, аманат ви бо̀ж'јй, [ГВ 193]; Аманат ми, ја је и не читам, [ГВ 2083].

Наведени изрази нису обрађени у једнотомном Рјечнику [уз пјесничка дјела П. П. Његоша]. У двотомном Речнику Његошева језика израз аманат ми лексикографски је описан у оквиру одреднице ама̀нат, док 1031. стих 
с Недићевим рашчлањивањем текста служи као илустрација за ријеч а̀ма̄н [Стевановић и др. 1983 I: 7]. Љуб. Стојановић је сугерисао Решетару: „У ст. 1031 место аманати, ваљало је написати амана ти (в. Вук, Рјеч., s. v. „,аманат”)« [Ст о Ан ов и ћ 1923: 397]. Вук Кара̀џић је, додуше, сматрао да је облик аманати настао од *аманата ти (што није тачно), али није у писању ријеч растављао. За друго значење именице аманат Вук каже: „Црногорци се и куну и заклињу аманетом: аманата ми Божјега! Кад другога кога заклињу онда се у говору често та изостави, па се говори н. п. аманати (мјесто аманата ти)" [КАРАџи 1852: 4, s. v. АмА́нАт]. А Милан Решетар се ипак држао Вука: у тексту је оставио: аманати, а уз 1031. стих додао (у посљедња два издања) коментар: „аманати говори се мјесто аманата ти" [РЕшЕТ АР 1928: 59; исто у Решет AP 1940: 59]. Исто тумачење се среће и у рјечнику („Додатак. Тумачење неколико ријечи у овој књизи”) уз издање Учитељског друштва „Натошевић”: „а м а н а т и, мјесто: аманата ти, аманета ти” [НАтошевић 1910: прва непагинирана страна на уметнутој четвртини табака].

Приређивачи Горског вијенца и лексикографи нису запазили да је правилно рашчлањивање израза дао Ђуро Даничић - у оквиру одреднице АмÁNAT он даје не само израз amanat mi из Горског вијенца него и стихове: Đе ga kupi aga? amanat ti!; A bješe li kakav? amanat ti! [RJEČNIK JAZU 1881 I (1): 78]. У црногорским говорима користи се акценатска варијанта ама̀нат.

Закључили смо да у Горском вијениу није посвједочена именица а̀ма̄н ‘вјера' у генитиву, нити конструкција ама́на ти, тако ти ама́на, него именица ама̀нат 'завјет' у номинативу у споју с енклитичким облицима датива личних замјеница другог лица једнине $m u$, другог лица множине ви (= вам) и првог лица једнине $м и$. При том је у вези с личном замјеницом другога лица елидиран облик императива трећег лица једнине буди < bqdi у значењу 'нека буде': аманат ти [буди], а у конструкцији с личном замјеницом првога лица - облик трећег лица једнине помоћног глагола je < jestъ: аманат ми [je].

(2) Растављено се пише веза прилога она̀ко̄ с енклитичким акузативом личне замјенице 3. лица једнине га: Онако га црна памет учи - [ШМ 3276]. Састављено писање у првом издању показује да је приређивач погрешно схватио фонетску ријеч - као супстантивизирани облик придјевске замјенице онаки (човјек): Онакога (с. 152). Грешка је исправљена већ у издању браће Јовановића: Онако га црна памет учи, [ЈовАновићи 1881: 126].

(3) Растављено се пише веза узвичне рјечце ё с обликом средњег рода једнине супстантивизиране показне замјенице то̂: ё тоि каже, честити вӓлйсу, [ШМ 1661]. Састављено писање у првом издању показује да је приређивач погрешно схватио фонетску ријеч - као рјечцу: Ето (с. 81). Грешка је поновљена у другом издању: Ето каже, честити валису! [ЈовАновићи 1881: 68], а исправљена у трећем: Е то каже, честити валису, [Кости 1902: 94 (1695)]. 
Милан Решетар се служио издањем браће Јовановића као протографом, па је ову грешку поновио: Ето каже, честити валису, [РешетАР 1926: 246 (II 818)]. Коначно је грешку исправио Данило Вушовић: Е то каже, честити валису, [Вушовит 1935: 203].

(4) Растављено се пише веза узвичне рјечце ӧ с вокативом антропонима: О Кану́ни*, највиши сӱлта̄не, [ШМ 1077]. Састављено писање у првом издању показује да је приређивач погрешно схватио први полустих - као да иницијални вокал припада антропониму: Окануни (с. 56). Грешка је исправљена већ у издању браће Јовановића: О Кануни, *) највиши султане! [Јов Ановићи 1880: 48].

11. Растављено пишемо придјевско-именичке синтагме иако је у њима, у аутентичном изговору, прва компонента атонирана а акценат пренесен с друге компоненте - (на) злу́ срећу [види даље т. (1)]; по свѐ љето [види даље т. (2)].

(1) Растављено се пише веза придјева (ак. ж.р.) злүิ и именице (ак.) срёћу и поред тога што је придјев атониран па је пренесен акценат с именице - (на) злý срећy: нагазићу на ве̂љӯ злу́ срећу. [ШМ 2402]. Растављено писање није било спорно од првог издања: злу срећу (с. 114).

(2) Растављено се пише веза придјевске замјенице свё и акузатива именице љёто у комбинацији с предлогом по и поред тога што је замјеница атонирана па је пренесен акценат с именице - по свѐ љето: ко̀д ва̄с ноћи по свѐ љето нѐj'мā, [ШМ 3370]. Растављено писање није било спорно од првог издања: по све љето (с. 156).

12. У критичком издању Шћепана Малог растављено пишемо предлошко-падежне везе које се нису (потпуно) граматикализовале, тј. које нису потпуно прешле у сложене предлоге с генитивом, и које чувају именичко значење и самосталан именички акценат (без преношења на примарни предлог) - „на срёд + генитив”, ,y днӧ + генитив”, „пӧ днӧ + генитив”, „са днӧ + генитив” и „на вё $x+$ генитив”, „са вё $x+$ генитив”, али се оне описују у раду Маројевић 2021a.

\section{III. ИСХОДИ}

13.1. Ми смо у овом раду користили метод интертекстуалне анализе поредећи примјер у анализираном контексту с другим контекстима у самом спјеву и у другим Његошевим дјелима, али то је уобичајени поступак у његошологији. Поредбену анализу користимо не само у синтагматској равни него и у парадигматској оси. Навешћемо примјере за парадигмаски приступ. 
У парадигму фразеологизма јё ли ѝ Бо̄г дӓо [ШМ 1214] улази његов сажети облик јё л' ̀̀ Бо̄г $\partial \bar{a}$ [ШМ 2695], у којем је рјечца и наглашена и не може бити елидирана.

Растављено писање компоненти везника $а$ кӓмо ли [види т. 4.(3)] подупире архаична конструкција са живим упитним прилогом $а$ кӓмо ли [је отишао?], од које је везник граматикализацијом и настао, а овај везник има свој синоним а тоि ли [види т. 4.(2)], који треба такође писати растављено и изговарати с акцентом који има средњи род показне замјенице уз друго лице $m \hat{o} ;$ исти изговор и растављено писање задржава овај везник и кад му се прва компонента изостави (тоิ ли) [види т. 4.(1)].

13.2. У истраживању смо користили метод семантичке замјене. Тако, у контекстима гдје се графија првог издања ка да може, у прозном тексту, замијенити синонимом 'изгледа', реконсруише се модална ријеч с дугоузлазним акцентом на првом слогу ( $\kappa a ́ d a)$, а гдје се она може замијенити варијантом 'као да', реконструипе се двокомпонентни везник ка̂ дӓ с побочним акцентима, али о томе подробније расправљамо у раду Маројевић $2021 б$.

13.3. У реконструкцији растављеног писања, као и у другим типовима вербализације текста, користе се, гдје год је то могуће, комплементарни методи. Илустроваћемо ту комплементарност са три примјера.

Нашу реконструкцију трећег такта у стиху: (кад нй с једнйм - онда) câм $u$ [c] сӧбомм [ШМ 2607] подупире: $1^{\circ}$ параметар филолошке (не)потврђености - у стиху не треба додавати сугласничку компоненту наставка као у Младеновићевој реконструкцији [c] сами[м] собом [види т. 1.(3)], и $2^{\circ}$ фразеолошки параметар - каже се за некога да (прича) сам са собом, а није уобичајено рећи да неко (прича) * са собом (без компоненте сам).

За реконструкцију растављеног писања у првом такту стиха: ва̂м и чӱти (смрти ни живота) [ШМ 3089] могу се навести два момента: $1^{\circ}$ није реално претпоставити да наш пјесник користи стари инструментал множине *вами умјесто датива двојинског поријекла вама, али јесте да употребљава архаични датив множине $в \hat{a} м ; 2^{\circ}$ замјенички дативи на̂м, ва̂м у Његошевом пјесничком језику су потврђени.

За реконструкцију растављеног писања у другом такту стиха: (а ја што̀ ћу), ӓл' $и$ (са ки́ме ћу) [ГВ 33] може се навести, с једне стране, $1^{\circ}$ критеријум смислености (састављено писање *али скоро да нема смисла), с друге стране, $2^{\circ}$ критеријум потврђености (двокомпонентни везник ӓл' $u$ у значењу 'а и' у Његошевом пјесничком језику је посвједочен). У стиху је остварено опкорачење границе између другог и трећег такта, али је то чест случај у Његошевој поезији.

13.4. Наша анализа од значаја је и за учење о врстама ријечи, али и за корекцију вокабулара у неком будућем Рјечнику Његошева језика, као и за 
попис у њему потврђених облика и њихових варијанти. Тако се у Његошевом пјесничком језику разликују именице ама̀нат (ген. ама̀нта) у основном значењу ‘завјет’ и у фразеолошкој употреби и ама́нет (ген. ама́нета) у основном значењу 'светиња' и у нефразеолошкој употреби.

\section{ИЗВОРИ}

ВГ: Виенацъ горскій [види факсимил аутографа рукописне верзије Горског вијениа Петра Петровића Његоша из 1846. године у: Александар Карађорђевић 1931; Павићевић 1985, 5-41; Миловић 1982].

ГВ: Горски вијенаи [у: Медаковић 1847: 1-116 (прво издање); Маројевић 2005: 35-222 (критичко издање); Маројевић 2018: 161-268 (основно издање); акценатско издање је у рукопису].

ЛМ: Луча микрокозма [у: Маројевић 2016: 19-101 (репринт првог издања), 105-224 (критичко издање), 903-1020 (акценатско издање); Маројевић 2018: 67-149 (основно издање)].

ПСР: Поздрав (србском) роду [Прилог у: Маројевић 2020: 487-490 (критичко издање), 1154-1155 (акценатско издање), Прилог II у: Маројевић 2018: 450-452 (основно издање)].

ШМ: Шћепан Мали [у: Маројевић 2020: 19-225 (репринт првог издања), 227-486 (критичко издање), 1011-1153 (акценатско издање), Маројевић 2018: 289-449 (основно издање)].

\section{ЛИТЕРАТУРА}

Александар Карађорђевић 1931: А. [= Александар Карађорђевић]. Виенащъ горскій. [Аутограф рукописне верзије Горског вијенйа Петра Петровића Његоша из 1846. године]. Љубљана.

Банашевић 1973: П. П. Његош, Горски вијенаи, Критичко издање с коментаром приредио Никола Банашевић, Београд: Српска књижевна задруга.

Драгићевић 1975: Ристо J. Драгићевић, Горски вијенац и коментари. Поводом посљедњег издања Српске књижевне задруге. [Критика издања: Банашевић 1973], Стварање, XXX/11, 1507-1531.

Бошковић и др. 1967: Петар Петровић Његош, Горски вијенаи. [Текст приредили за штампу Р. Бошковић, В. Латковић. Белешке и објашњења написао В. Латковић]. Луча микрокозма. [Текст приредили за штампу Н. Банашевић, Р. Бошковић. Белешку написао Н. 
Банашевић. Објашњења написао В. Павићевић]. Београд: Просвета. (Целокупна дела Петра Петровића Његоша. [ІІ изд.] Књ. 3).

Бошковић/Латковић 1952/1957: Петар Петровић Његош, Горски вијенаи. [Текст приредили за штампу Радосав Бошковић и Видо Латковић. Биљешке и објашњења написао Видо Латковић], Београд: Просвета, 1952. (Цјелокупна дјела П. П. Његоша. Књ. 3). [Додатни тираж: 1957].

Вуловић 1886: [Свет. Вуловић.] Његушев «Горски вијенач» у немачком преводу: Прештампано из «Самоуправе». Београд. [Претходно објављено у: Самоуправа, Београд, 18. јуна 1886, I, бр. 40, 1-2; 19. јуна 1886, I, бр. 41, 1-2; 20. јуна 1886 , I, бр. 42, 1-3; 22. јуна 1886, I, бр. 43, 1-2; 17. јула 1886, I, бр. 64, 2-3; 19. јула 1886, I, бр. 66, 1; 20. јула 1886, I, бр. 67, 1; 22. јула 1886, I, бр. 69, 1; 24. јула 1886, I, бр. 71, 1; 27. јула 1886, I, бр. 73, 1-2].

Вушовић 1930: Д. В. Вушовић, Прилози проучавању Његошева језика, Јужнословенски филолог, IX, 93-196.

Вушовић 1930б: Д. В. Вушовић, Прилози проучаваюу Његошева језика, Београд: Библиотека Јужнословенског филолога.

Вушовић 1935: Цјелокупна дјела Петра Петровића Његоша. У редакцији Данила Вушовића. Београд: Народна култура.

Вушовић 1936: Цјелокуина дјела Петра II Петровића Његоша. У редакцији Данила Вушовића. Друго издање. Београд: Народна култура.

Јовановићи 1880: Лажни цар Шћепан Мали: Историјско збитије XVIII. вијека. Сачинио Петар Петровић Његуш владика црногорски. Ново издање. Панчево: Накладом Књижаре браће Јовановића, [1880]. (Народна библиотека браће Јовановића. Св. 5).

Јовановићи 1881: [Само на корицама:] Лажни иар Шћепан Мали. [Панчево, 1881], 65-152. (Народна библиотека браће Јовановића. Св. 7).

Караџић 1852: Српски рјечник истумачен њемачкијем и латинскијем ријечима, Скупио га и на свијет издао Вук Стеф. Караџић, У Бечу. [Фототипско издање: Београд, 1977].

Ковачевић 1940: Горски вијенац. Историческо собитије при свршетку XVII вијека. Сочиненије Петра Петровића Његоша, [Приредио Божидар Ковачевић]. Београд.

Костић 1902: Лажни цар Шћепан Мали: Историческо збитије осамнаестога вијека. Од Петра Петровића Његоша. [Предговор написао Јаша М. Продановић. Приредио Драгутин Костић]. Београд-Загреб: 
Штампарија Мила Маравића, 1902. (Српска књижевна задруга, 63). [Првом пагинацијом штампани су, накнадно, предговор и биљешка о издању потписана са С. К. 3.].

Лалић и др. 1953: Петар Петровић Његош. Пјесме. Луча микрокозма. Проза. Пријеводи. [Текст Пјесама, Прозе и Пријевода приредили за штампу Радован Лалић и Михаило Стевановић. Текст Луче микрокозма приредили за штампу Никола Банашевић и Радосав Бошковић. Биљешке и објашњења уз Пјесме, Прозу и Пријеводе написао Радован Лалић. Биљешку уз Лучу микрокозма написао Никола Банашевић. Објашњења уз Лучу микрокозма написао Вуко Павићевић]. Београд: Просвета. (Цјелокупна дјела П. П. Његоша. Књ. 2).

Лалић 1967: Петар Петровић Његош, Пјесме / Текст приредио, белешке и објашњења написао Радован Лалић, Београд: Просвета. (Целокупна дела Петра Петровића Његоша. [II изд.] Књ. 1).

Маројевић 2005: Петар II Петровић-Његош, Горски вијенаи. Критичко издање. Текстологија. Редакција и коментар Радмило Маројевић, Подгорица: ЦИД.

Маројевић 2016: Петар II Петровић-Његош, Луча микрокозма. Критичко издање. Текстологија, Редакција и коментар Радмило Маројевић, Подгорица: ЦИД - Цетиње: Narodni muzej Crne Gore.

Маројевић 2018: Петар II Петровић-Његош, Луча микрокозма. Горски вијенаи. Шћепан Мали. Основно издање. Ортографија и ортоепија, Редакција и коментар Радмило Маројевић, Никшић: Будимљанско-никшићка епархија - Београд: Друштво за неговање Његошевог дела.

Маројевић 2020: Петар II Петровић-Његош, Шћепан Мали. Критичко издање. Текстологија, Редакција и коментар Радмило Маројевић, Подгорица: ЦИД - Цетиње: Народни музеј Црне Горе.

Маројевић 2021a: Радмило Маројевић. Адвербијализација предлошко-падежних веза (на грађи Његошевог Шћепана Малог). Зборник Матице српске за филологију и лингвистику, LXIV/1.

Маројевић 2021б: Радмило Маројевић, Вербализација текста Шћепана Малог (Реконструкција састављеног писања), Зборник Матище српске за филологију и лингвистику, LXIV/2.

Маројевић 2021в: Радмило Маројевић. Специфичне морфеме и иновације у структури врста ријечи (на грађи Његошевог Шћепана Малог). Зборник радова Филозофског факултета Универзитета у Приштини, Косовска Митровица, LI/1. 
Медаковић 1847: Горскій віенащъ[.] Историческо событіє при свршетку XVII віека. Сочиненіє П[етра] П[етровића] Н[вгоша,] владыке црного[р]скога. [Приредио Милорад Медаковић], У Бечу: словима ч[астнихъ] о[таца] мехитариста.

Миловић 1965: Петар II Петровић Његош, Лажни цар Шћепан Мали. [Приредио за штампу и прилоге написао Јевто М. Миловић], Титоград: Графички завод. (Библиотека „Луча”, 15).

Milović 1965: Jevto Milović, Neka pitanja kritike teksta »Gorskoga vijenca« (Povodom izdanja »Gorskoga vijenca« u redakciji Rista J. Dragićevića), Zadarska revija, XIV/1, 53-69. [Прештампано ћирилицом у: Миловић 1983, 363-384].

Миловић 1982: Јевто М. Миловић, Рукопис „Горског вијенца” Петра II Петровића Његоша, Титоград: Црногорска академија наука и умјетности.

Миловић 1983: Јевто М. Миловић, Стазе ка Његошу, Титоград: Унирекс.

Младеновић 1996: Петар II Петровић Његош, Горски вијенаи, Приредио Александар Младеновић, Цетиње: Обод. (Књижевност Црне Горе од XII до XIX вијека).

Младеновић 2007: Петар II Петровић Његош, Лажни ияар Шћепан Мали, Приредио Александар Младеновић. Подгорица: ЦАНУ. (Сабрана дјела Петра II Петровића Његоша. Критичко издање. Књ. 3).

Натошевић 1910: Горски Вијенаи. Историјски догађај при свршетку XVII вијека, Сачинио Петар Петровић-Његош, У Новом Саду: Издање Књижаре и штампарије учитељског д. д. „Натошевић”.

Недић 1964: Петар Петровић Његош, Лажни цар Шћепан Мали. Писма. [Избор Војислав Ђурић. Редакција Владан Недић], Нови Сад: Матица српска - Београд: Српска књижевна задруга. (Српска књижевност у сто књига. Књ. 22. Петар Петровић Његош, II).

Недић 1969: Петар Петровић Његош, Лажни цар Шћепан Мали. Писма. [Избор Војислав Ђурић. Редакција Владан Недић], Нови Сад: Матица српска - Београд: Српска књижевна задруга. (Српска књижевност у сто књига. Књ. 19. Петар Петровић Његош, II).

Остојић 1996: Бранислав Остојић, О значењу и ортографији неких ријечи и израза у Горском вијениу, Српски језик, I/1-2, 205-214. [Прештампано у: Остојић 1997: 196-209].

Остојић 1997: Бранислав Остојић, Прилози о Његошеву језику, Никшић: Никшићке новине. 
Павићевић и др. 1985: Петар II Петровић-Његош, Горски вијенаи, Уредник Бранко Павићевић, Титоград: Црногорска академија наука и умјетности и др. Издање садржи факсимил рукописа (5-41) и репринт првог издања (43-169).

Решетар 1890: Горски вијенаи владике црногорскога Петра Петровића Његоша, Увод и коментар написао Милан Решетар, У Загребу.

Решетар 1926: [Целокупна дела Петра Петровића Његоша. Књига прва. Већа дела]. Горски вијенаи. Луча микрокозма. Шћепан Мали, У редакцији Милана Решетара, Београд: Државна штампарија.

Решетар 1923: Горски вијенаи владике црногорскога Петра Петровића Његоша, Осмо издање с коментаром Милана Решетара, Биоград.

Решетар 1928: Горски вијенаи владике црногорскога Петра Петровића Његоша, Девето издање с коментаром Милана Решетара, Биоград.

Решетар 1940: Горски вијенаи владике црногорскога Петра Петровића Његоша, Десето издање с уводом и коментаром Милана Решетара, Београд.

Rječnik JAZU 1881 I (1): Rječnik hrvatskoga ili srpskoga jezika. Na svijet izdaje Jugoslavenska akademija znanosti i umjetnosti, Obrađuje Đ. Daničić. Dio I. Svezak 1. U Zagrebu. S. 1-240. Reprint 1981.

Стевановић 1952: Петар Петровић Његош, Шћепан Мали. [Текст приредили за штампу Михаило Стевановић и Радован Лалић. Биљешке и објашњења написао Михаило Стевановић], Београд: Просвета. (Цјелокупна дјела П. П. Његоша. Књ. 4).

Стевановић 1967: Петар Петровић Његош, Шћепан Мали. [Текст приредио, белешке и објашњења написао Михаило Стевановић]. Проза $u$ nреводи. [Текст приредио, белешке и објашњења написао Радован Лалић], Београд: Просвета. (Целокупна дела Петра Петровића Његоша. [II изд.]. Књ. 4).

Стевановић 1974: Петар Петровић Његош, Шћепан Мали. [Текст приредио, белешке и објашњења написао Михаило Стевановић]. Проза. Преводи. [Текст приредио, белешке и објашњења написао Радован Лалић], Београд: Просвета. (Целокупна дела Петра Петровића Његоша. ІІІ изд. Књ. 4).

Стевановић 1975: Петар Петровић Његош, Шћепан Мали. [Текст приредио, белешке и објашњења написао Михаило Стевановић]. Проза. Преводи. [Текст приредио, белешке и објашњења написао Радован Лалић], Београд: Просвета. (Целокупна дела Петра II Петровића Његоша. IV изд. Књ. 4). [Фототипија III изд.]. 
Стевановић 1976: Михаило Стевановић, Језичка тумачењ а у коментарима Његошева Горског вијениа, Београд: Српска академија наука и уметности.

Стевановић 1990: Михаило Стевановић, О језику Горског вијенияа, Београд: Српска академија наука и уметности, Научна књига.

Стевановић и др. 1983 I: Речник језика Петра II Петровића Његоша. [На корицама: Речник Његошева језика]. Израдили Михаило Стевановић и сарадници Милица Вујанић, Милан Одавић и Милосав Тешић. Уредник Михаило Стевановић. Књ. І. Београд: Српска књижевна задруга и др., 1983.

Стевановић и др. 1983 II: Речник језика Петра II Петровића Његоша. [На корицама: Речник Његошева језика]. Израдили Михаило Стевановић и сарадници Милица Вујанић, Милан Одавић и Милосав Тешић. Уредник Михаило Стевановић. Књ. II. Београд: Српска књижевна задруга и др., 1983.

Стевановић/Бошковић 1954/1957: Рјечник [уз пјесничка дјела П. П. Његоша]. [Рјечник саставили Михаило Стевановић и Радосав Бошковић]. Београд: Просвета, 1954. (Цјелокупна дјела П. П. Његоша. Књ. 6). [Додатни тираж: 1957].

Стојановић 1923: Љуб. Стојановић, [Критика издања: Решетар 1923], Просветни гласник, XL/5, 331-334, XL/6, 394-397 (друге пагинације).

Стојковић 1851: Лажни изар Шћепан Мали: Историческо Збитије Осамнајестога вијека. Пјесмотворје Његове Свијетлости Петра Петровића Његоша, Владике и Господара Црнегоре. [На 9. страни:] Шћепан Мали. Повјестно збитије, у пет дјејствијах. [На насловној страни:] Издао 1851. године Андрија Стојковић у Трсту. [На корици:] У Југославији. [На полеђини насловне стране испод мота:] Печатња браће Жупана у Загребу 1851. 


\section{ВЕРБАЛИЗАЦИЯ ТЕКСТА В ПОЭМЕ «ЩЕПАН МАЛЫЙ» ПЕТРА НЕГОША \\ (1. РЕКОНСТРУКЦИЯ РАЗДЕЛЬНОГО НАПИСАНИЯ) \\ Р е $з$ ю е}

В серии статей под этим названием критически обосновывается подготовленное автором научное издание поэмы «Щепан Малый» сербского поэта эпохи романтизма Петра II Петровича-Негоша на уровне текста.

В настоящей статье серии рассматриваются спорные вопросы реконструкции раздельного написания словосочетаний, в то время как в других статьях серии будег рассмотрено слитное и дефисное написание, а текже интерпретация дивербов в разных типах изданий. Исследование, преследуемое не только практические цели, строится на основе теории о вербализации текста, а также на учении о частях речи в сербском язвке. Заключительные этюды статьи посвящены дополнительным методам в текстологической теории и практике.

В работе применяется интертекстуальный сопоставительный подход: примеры, засвидетельствованные в поэме «Щепан Малый», сравниваются с контекстами поэм Негоша «Горный венец» и «Луч микрокосма».

Ключевые слова: Петр II Петрович-Негош, поэма «Щепан Малый», поэма «Горный венец», поэма «Луч микрокосма», учение о частях речи. 